\title{
Neo-Liberalism, Austerity and the Political Determinants of Health
}

\section{A. M. Viens ${ }^{1}$}

Published online: 11 July 2019

๑) Springer Science+Business Media, LLC, part of Springer Nature 2019

Medicine is a social science, and politics nothing but medicine at a larger scale.

\section{Rudolf Virchow}

We should think of medicine as a social science, according to Virchow, because he understood the various ways in which social inequality is a contributor to and cause of ill-health. With social inequality having a central impact on the ability of people and populations to be healthy, it is political action around these states of affairs that determines the extent of our success in the prevention and mitigation of ill health. But this relationship is not merely descriptive, it is also normative in two important ways. First, the social environment, and not individual factors, is what makes living healthy lifestyles difficult to sustain. This makes collective action and adequate funding necessary to assure the social conditions under which people can be healthy a shared responsibility across society-providing a vital role for the state in these efforts [7]. Second, the social mission and social machinery needed to understand and advance the state's health responsibilities to assure conditions under which people can be healthy establishes a key role for political morality in determining what forms and means of co-ordination is required to meet these responsibilities [6]. These normative considerations demonstrate that ill health and social inequalities are not merely matters for epidemiologists to map and measure-they are also of central concern to moral and political theorists to understand why there is an imperative to address them and establish the means by which it would be justified to do so. Crucially, however, the state can also use its power and political action to adopt ideological and policy positions that promulgate ill health and health inequality. A neo-liberal political ideology and its use of economic policies such as austerity have had a devastating effect on health and health equity.

\section{A. M. Viens}

hca.springer@gmail.com

1 Faculty of Health, York University, Toronto, Canada 


\section{Health and Health Equity Under Neo-Liberalism}

Neo-liberalism is a political ideology which is premised on market-based values, such as individual choice, competitiveness, consumerism, economic liberalization, efficiency, privatization, and profit maximization [9, 14]. These individualistic values, in turn, go on to shape and prioritize particular ideas that are propagated in how and where the state operates, including its economic and health policies. Within many different high-income nations, the hegemony of neo-liberal ideology pervades how we have come to understand health, how healthcare should be structured and how we should respond to health issues. Two central underlying concepts are commodification and individual responsibility — which have a direct and negative impact on health and health equity.

Under neo-liberalism, we should understand health as a particular kind of economic good; as a commodity governed by market principles. It is claimed that doing so will ensure that health services are structured in a way that maximize its instrumental value by producing more efficient and innovative care-compared to how health services are structured under a welfare state system. Health tends to become a negatively defined value (i.e., as the absence of disease), which encourages a problem of overstating healthcare as a determinant of health with market-based responses that focus on remediation. The move away from state-based governance to market-based governance and the commodification of health also has other important knock on effects-for instance, as a commodity best governed by the market, healthcare (and even the determinants of health, such as education and housing) are not to be understood as a right. Health is not special; it is just another instrumental good that can be traded-off against other (it presumes commensurate) goods-often to the detriment of the least advantaged, which only serves to bolster health inequity.

As a commodity that is thought to be best structured under market conditions in which individuals are free to choose the amount and type of health coverage desired, we have also seen a focus on responsibility for health being shifted to the individual under neo-liberalism. As such, we see neo-liberal states taking a lighter touch when it comes to helping people achieve better health. As Kay and Williams note:

An important aspect of neoliberalism in healthcare is the development of indirect techniques for leading and controlling individuals without being responsible for them. In line with its desire to privatise risk, neoliberal healthcare states use the technique of responsibilisation; citizens become 'responsibilised' by making them see health risks and outcomes such as illness or disease as their own individual responsibility, with the corollary that the policy problem of health governance is framed as one of encouraging 'self-care' [19].

In the realm of public health, we see a movement to prefer less restrictive interventions in the form of public awareness/education campaigns and minimalist behaviour change interventions, such as nudges. ${ }^{1}$ The preservation of individual

\footnotetext{
1 This is also underpinned by defaults and presumptions found in apparently friendly public health ethics positions, e.g., Nuffield Council on Bioethics (2007). Public Health: Ethical Issues. London: Nuffield Council on Bioethics. For an excellent objection, see Dawson, A. (2006). Snakes and ladders: state interventions and the place of liberty in public health policy. Journal of Medical Ethics 42, 510-513.
} 
autonomy and the promotion of individual responsibility are dogmatically pursued despite the evidence we have about the importance of structural determinants of health, especially the role of political and commercial determinants of health at the national and global levels.

\section{Political Determinants of Health and Health Equity: The Case of Austerity in the UK}

Neo-liberal economic policy depends on continued economic growth, so in times of economic difficulty, austerity measures (primarily through cutting social spending) are often presented as a natural response that must be instituted until the economy can rebound. This was evident in much of the political activity and policy of the Conservative government over the last decade in the UK. While the pervasiveness of neo-liberal ideology within many Western nations makes recourse to austerity seem inevitable, it is a political choice guided by a particular political morality. We can and should evaluate both the success and morality of that choice. Austerity has been a massive failure and its consequences have been morally repugnant for the direct and indirect effects it has had on health and health equity. This is true not only for the UK, but elsewhere [2, 4, 30, 31, 34].

The austerity debate is often conducted using a false equivalence between one's individual bank account and national economies. Proponents of austerity disingenuously claim that just as we would not be fiscally responsible to run a deficit or go into further debt in our personal finances, it would be similarly so for government spending. We hear familiar refrains that times are tough or that we all have to come together and share the pain. These hypocritical mantras mask the real story, which the evidence bears out. The pain is not equitably divided across all society-and certainly not distributed in a way that puts the burdens on those who can most bear its weight. Instead, in places such as the UK, we see that it is the economically disadvantaged and socially vulnerable who bear the brunt. The severe cuts in government spending instituted since the 2007-8 financial crisis-which disproportionally targeted some of the most vulnerable in society - stifled economic growth, provided less tax revenue, increased deficits and choked off funding to the National Health Service $[22,33]$. The effects of austerity on health and health equity have been devastating: mortality has increased (including preventable deaths) [12, 17, 36], life expectancy has stalled [26], social care is colossally underfunded [5, 10, 35], childhood and pensioner poverty is rising [8, 18], rough sleeping, homelessness, and dependence on food banks has massively risen [23, 27].

The consequences of austerity from past cuts and current shortfalls continue to negatively impact health and well-being. The pressure on public health and wider budgets with a $£ 5.8$ billion funding gap will only ensure that the effects will be felt for generations to come [25]. Austerity has also been used as an excuse to fundamentally reshape how health services are structured and delivered-especially downloading significant health responsibilities to local governments who are struggling to cope $[11,15,16,24]$. The efforts to use austerity to push the neo-liberal project only seek to deepen and normalise their conception of health-that it is 
primarily about the individual, that market-based governance can do it better, that an unequal distribution of health status is normal, etcetera. The neo-liberal governance of capitalist economic activity affects all aspects of health, especially the environmental determinants of health. Much of the work being done to curb and reform the kind of economic activity that is driving climate change, for example, should be part and parcel with the work being done to curb austerity.

Austerity provides a stark illustration of the impact of the political determinants of health and health equity, but even outside of austerity we have seen how a neoliberal approach to politics can have a significant and very worrying toll on our health systems. Neo-liberal agendas to cut taxes, which drive up debt and deficits, which then provide a justification for the need to implement spending cuts, institute user fees or accelerate privatization when we are told we cannot afford health and social programmes seek to reinforce a particularly insidious political morality. Under neo-liberalism, governments always seem to find enough money and political will to bail out failing banking systems, fund a war or support tax breaks and subsidies for corporations, but it seems we never should run similar debts or deficits to assure the conditions under which we can enjoy health and health equity. This needs to change, which will need good health sciences, social sciences and humanities research to help demonstrate why and how this can be achieved.

\section{Normative Analysis of Political Determinants: Future Programmes of Work}

As the contributions to this special issue and the wider literature on health and austerity show, we have very good empirical and moral reasons to reject austerity as a political choice and neo-liberalism as an ideological choice. For scholars, practitioners and advocates who reject austerity and neo-liberalism, however, merely levying evidence and reasons against them is only part of the work. For there to be the best chance for policy-makers to reject austerity and neo-liberalism, we are also going to need a programme of work that can develop positive proposals and policy options [32]. Work on such policy proposals are gaining wider support-take, for instance, universal healthcare and universal basic income-but we are going to need further positive proposals that are implementable alternatives to austerity and neo-liberalism. Future programmes of work are needed to explore and develop these political alternatives and the role they can play in determining the health status and the equity with which it is distributed across groups and societies. It would also be useful for further work to be done challenging the rhetoric around neo-liberalism and the fallacious metaphors it relies upon, which are too often blindly accepted as truisms or apt comparisons.

The time has come to devote much greater attention to the political determinants of health and health equity - and to the contribution of political philosophy, political science and legal epidemiology to questions around how these determinants function and how we should respond to them with policy, practice and advocacy. We need to explore substantially transformative yet implementable proposals towards 
promoting health and well-being, rectifying growing health inequity, empowered communities and finding sustainable ways of ensuring health justice for all.

\section{Conclusion}

The recognition of the political nature of health and an appreciation of the political determinants of health are absolutely key to better understanding ill health and health inequality, as well as our shared responsibility to ensure the conditions under which people can enjoy health and health equity. There is a pressing need to build on the body of work that helps us understand and illustrate the importance of political activity and public policy as a determinant of health [1, 3, 13, 20, 21, 28, 29]. Not only can it help us explain the different ways in which political power and ideology influence health and health equity, it reminds us of the need to justify the values and concepts that underpin them. This will not only contribute to more realistic and effective research on the political determinants of health and health equity, but also underscores the need to embrace research programmes and political agendas that can design and implement policies that provide feasible and attractive alternatives to the prevailing orthodoxy of neo-liberal ideas.

\section{References}

1. Barnish, M., Tørnes, M., \& Nelson-Horne, B. (2018). How much evidence is there that political factors are related to population health outcomes? An internationally comparative systematic review BMJ Open, 8, e020886.

2. Basu, S., Carney, M. A., \& Kenworthy, N. J. (2017). Ten years after the financial crisis: The long reach of austerity and its global impacts on health. Social Science and Medicine, 187, 203-207.

3. Bellido, H., Olmos, L., \& Román-Aso, J. A. (2019). Do political factors influence public health expenditures? Evidence pre- and post-great recession. The European Journal of Health Economics, 20, 455-474.

4. Blyth, M. (2013). Austerity: The history of a dangerous idea. Oxford: Oxford University Press.

5. Burchardt, T., Obolenskaya, P., \& Vizard, P. (2016). Adult social care. In R. Lupton, et al. (Eds.), Social policy in a cold climate: Policies and their consequences since the crisis (pp. 187-216). Bristol: Polity.

6. Coggon, J. (2012). What makes health public? Cambridge: Cambridge University Press.

7. Coggon, J., \& Viens, A. M. (2017). Public health ethics in practice. London: Public Health England.

8. Department of Work and Pensions (2019). Households below average income (HBAI) statistics. London: UK Government. https://www.gov.uk/government/collections/households-below-averageincome-hbai--2.

9. Eagleton-Pierce, M. (2016). Neoliberalism: The key concepts. London: Routledge.

10. Graby, S., \& Homayoun, R. (2019). The crisis of local authority funding and its implications for independent living for disabled people in the United Kingdom. Disability and Society, 34, 320-325.

11. Gray, M., \& Barford, A. (2018). The depths of the cuts: The uneven geography of local government austerity. Cambridge Journal of Regions, Economy and Society, 11, 541-563.

12. Green, M., Dorling, D., \& Minton, J. (2017). The geography of a rapid rise in elderly mortality in England and Wales, 2014-2015. Heath and Place, 44, 77-85.

13. Greer, S. L., et al. (2018). Political analysis in public health: Middle-range concepts to make sense of the politics of health. European Journal of Public Health, 28, 3-6.

14. Harvey, D. (2007). A brief history of neoliberalism. Oxford: Oxford University Press.

15. Hastings, A., et al. (2015). The cost of the cuts: The impact of local government and poorer communities. London: Joseph Rowntree Foundation. 
16. Heald, D., \& Steel, D. (2018). The governance of public bodies in times of austerity. The British Accounting Review, 50, 149-160.

17. Hochlaf, D., Quilter-Pinner, H., \& Kibasi, T. (2019). Ending the blame game: The case for a new approach to public health and prevention. London: Institute for Public Policy Research.

18. Human Rights Council (2019). Report of the Special Rapporteur on extreme poverty and human rights on his visit to the United Kingdom of Great Britain and Northern Ireland. Geneva: United Nations. Retrieved July 9, 2019 from https://undocs.org/A/HRC/41/39/Add.1.

19. Kay, A., \& Williams, O. (2009). Introduction: The international political economy of global health governance. In A. Kay \& O. D. Williams (Eds.), Global health governance: Crisis, institutions and political economy (pp. 1-24). NY: Palgrave Macmillan.

20. Kickbusch, I. (2005). Tackling the political determinants of global health. BMJ, 331, 246.

21. Kickbusch, I. (2015). The political determinants of health-10 years on. BMJ, 350, h81.

22. Krugman, P. (2015). The austerity delusion-The case for cuts was a lie. Why does Britain still believe it? The Guardian. Retrieved July 9, 2019 from https://www.theguardian.com/business/nginteractive/2015/apr/29/the-austerity-delusion.

23. Lambie-Mumford, H., \& Green, M. A. (2017). Austerity, welfare reform and the rising use of food banks by children in England and Wales. Area, 49, 273-279.

24. Lobao, L., Gray, M., Cox, K., \& Kitson, M. (2018). The shrinking state? Understanding the assault on the public sector. Cambridge Journal of Regions, Economy and Society, 11, 389-408.

25. Local Government Association. (2017). Growing places: Building local public services for the future (p. 6). London: Local Government Association.

26. Marmot, M. (2019). The Marmot review 10 years on. London: Health Foundation. Retrieved July 9 , 2019 from https://www.health.org.uk/news-and-comment/blogs/the-marmot-review-10-years-on.

27. Ministry of Housing, Communities, \& Local Government. (2018). Rough sleeping statistics Autumn 2017. London: UK Government. https:/www.gov.uk/government/statistics/rough-sleeping-in-engla nd-autumn-2017.

28. Muntaner, C., et al. (2011). Politics, welfare regimes, and population health: Controversies and evidence. Sociology of Health and Illness, 33, 946-964.

29. Navarro, V., et al. (2006). Politics and health outcomes. The Lancet, 368, 1033-1037.

30. Ruckert, A., \& Labonté, R. (2017). Health inequalities in the age of austerity: The need for social protection policies. Social Science and Medicine, 187, 306-311.

31. Schui, F. (2014). Austerity: The great failure. New Haven: Yale University Press.

32. Stiglitz, J. (2019). Neoliberalism must be pronounced dead and buried. What's next? The Guardian. Retrieved July 9, 2019 from https://www.theguardian.com/business/2019/may/30/neoliberalismmust-be-pronouced-dead-and-buried-where-next.

33. Stirling, A. (2019). Austerity is subduing UK economy by more than 3600 per household this yeareconomy supressed by almost 100 bn in 2018/19 Alone. New Economics Foundation. Retrieved July 9, 2019 from https://neweconomics.org/2019/02/austerity-is-subduing-uk-economy-by-more-than3-600-per-household-this-year.

34. Stuckler, D., \& Basu, S. (2013). The body economic: Why austerity kills. New York: Basic Books.

35. Thorlby, R., et al. (2018). What's the problem with social care, and why do we need to do better?. London: The King's Fund.

36. Watkins, J., et al. (2017). Effects of health and social care spending constraints on mortality in England: A time trend analysis. British Medical Journal Open, 7, e017722.

Publisher's Note Springer Nature remains neutral with regard to jurisdictional claims in published maps and institutional affiliations. 